\title{
БІОТЕХНОЛОГІЯ
}

УДК 577.12: 582.923.1

doi: 10.25128/2078-2357.20.3-4.6

${ }^{1}$ Л. Р. ГРИЦАК, ${ }^{2}$ В. М. МЕЛЬНИК, ${ }^{1}$ М. З. ПРОКОП' ЯК, ${ }^{1}$ О. Ю. МАЙОРОВА,

${ }^{1}$ Х. М. КОЛІСНИК, ${ }^{1}$ Н. М. ДРОБИК

${ }^{1}$ Тернопільський національний педагогічний університет імені Володимира Гнатюка

вул. М. Кривоноса, 2, Тернопіль, 46027

e-mail: drobyk.n@gmail.com

${ }^{2}$ Інститут молекулярної біології і генетики НАН України

вул. Акад. Заболотного, 150, Київ, 03143

e-mail: v.m.melnyk@imbg.org.ua

\section{ВМІСТ ФЛАВОНОЇДІВ І КСАНТОНІВ У КАЛЮСНИХ КУЛЬТУРАХ РОСЛИН ВИДІВ РОДУ GENTIANA L. 3А ВИРОЩУВАННЯ У РІДКОМУ ЖИВИЛЬНОМУ СЕРЕДОВИЩІ НА ПОРОЛОНОВИХ ПІДКЛАДКАХ}

Досліджено вміст флавоноїдів і ксантонів у калюсних культурах кореневого походження від рослин шести видів роду Gentiana L. за вирощування цих культур у рідких живильних середовищах на поролонових підкладках. Встановлено, що у більшості калюсних культур, які вирощували як на агаризованому, так і на поролоновому субстратах, вміст біологічно активних речовин був більшим або близьким до такого в коренях дикорослих рослин, але нижчим порівняно з їхніми пагонами. Вміст флавоноїдів і ксантонів у культурі тканин, які вирощували у рідких живильних середовищах, перевищував або був близьким порівняно 3 такими показниками у відповідних калюсах на агаризованих субстратах. У калюсі G. pneumonanthe (вигодська популяція) при культивуванні як на агаризованому середовищі, так і у рідкому середовищі на поролонових підкладках, флавоноїдів і ксантонів не виявлено.

Ключові слова: види роду Gentiana L., культура in vitro, поролонові підкладки, флавоноїди, ксантони.

Важливим завданням біотехнологічних досліджень, спрямованих на отримання альтернативного джерела лікарської рослинної сировини, $\epsilon$ не лише інтенсивний ріст культури тканин, але й iї здатність до синтезу тих чи інших вторинних метаболітів. Поряд із цим, відомо, що у багатьох випадках синтез вторинних сполук поліпшується у разі уповільнення або призупинення росту культури [5]. Тому, важливо підібрати умови росту культур in vitro, які б забезпечували як приріст біомаси, так і синтез у них біологічно активних речовин (БАР).

Актуальним $€$ використання біотехнологічних підходів отримання рослинної сировини для рідкісних лікарських рослин. До таких рослин належать види роду Gentiana L. Ciм видів роду занесені до Червоної книги України і мають природоохоронний статус: зникаючі (G. nivalis L., G. utriculosa L., G. verna L.), вразливі (G. lutea L., G. punctata L.), рідкісні (G. acaulis L., G. laciniata Kit. ex Kanitz) [15]. Крім цього, рослини цих видів знайшли широке застосування у світовій офіцинальній та народній медицині. Лікувальні властивості рослин обумовлені синтезом у їхній підземній та надземній частинах широкого спектру БАР іридоїдів, алкалоїдів, ксантонів, флавоноїдів, фенолкарбонових кислот тощо, дія яких на 
організм людини проявляється у регуляції діяльності травної, дихальної, видільної систем, поліпшенні обміну речовин в організмі тощо $[3,8,11,14,17]$.

Раніше нами підібрано умови індукції калюсу та його проліферації для семи видів роду Gentiana $[4,7,16]$. Для зменшення трудомісткості матеріальних затрат, а, отже, і собівартості отриманої біомаси нами розроблено спосіб тривалого культивування калюсних тканин кореневого походження тирличів на поролонових підкладках у рідкому живильному середовищі [13]. Встановлено здатність більшості калюсних культур до інтенсивнішого росту у рідкому живильному середовищі на поролонових підкладках порівняно з агаризованим $[4,13]$.

Метою цього дослідження є оцінка вмісту флавоноїдів і ксантонів у калюсах тирличів, які вирощували у рідкому живильному середовищі на поролонових підкладках, та порівняння ïx $з$ аналогічними показникам калюсів за їх вирощування на агаризовному субстраті, а також коренів і пагонів рослин 3 природних місць росту.

\section{Матеріал і методи досліджень}

Для дослідження використовували дикорослі рослини та культури тканин, отримані від рослин видів роду Gentiana флори України (табл. 1).

Таблиия 1

Місця зростання досліджених зразків тирличів

\begin{tabular}{|c|c|c|c|}
\hline Вид & Місце зростання & $\begin{array}{c}\text { Висота над } \\
\text { рівнем моря (м) }\end{array}$ & $\begin{array}{c}\text { Умовні } \\
\text { позначення }\end{array}$ \\
\hline \multirow{2}{*}{ G. lutea } & $\begin{array}{c}\text { полонина Рогнєска } \\
\text { (хребет Чорногора, Рахівський р-н, } \\
\text { Закарпатська обл.) }\end{array}$ & 1650 & G.1.R \\
\hline & $\begin{array}{l}\text { г. Трояска } \\
\text { (хребет Свидовець, Рахівський р-н, } \\
\text { Закарпатська обл.) }\end{array}$ & 1695 & G.1.Tr \\
\hline G. punctata & $\begin{array}{c}\text { г. Брескул } \\
\text { (хребет Чорногора, Надвірнянський р-н, Івано- } \\
\text { Франківська обл.) } \\
\end{array}$ & 1790 & G.p.Br \\
\hline G. acaulis & $\begin{array}{c}\text { г. Туркул } \\
\text { (хребет Чорногора, Рахівський р-н, } \\
\text { Закарпатська обл.) }\end{array}$ & 1750 & G.ac.T \\
\hline G. asclepiadea & $\begin{array}{c}\text { г. Пожижевська } \\
\text { (хребет Чорногора, Надвірнянський р-н, Івано- } \\
\text { Франківська обл.) }\end{array}$ & 1424 & G.asc.P \\
\hline \multirow{2}{*}{ G. cruciata } & $\begin{array}{c}\text { с. Креничі } \\
\text { (Обухівський р-н, Київська обл.) }\end{array}$ & - & G.cr.Kr \\
\hline & $\begin{array}{c}\text { природний заповідник «Медобори» } \\
\text { (Гусятинський р-н, Тернопільська обл.) }\end{array}$ & - & G.cr.Med \\
\hline $\begin{array}{l}\text { G. pneumo- } \\
\text { nanthe }\end{array}$ & $\begin{array}{c}\text { c. Вигода } \\
\text { (Долинський р-н, Івано-Франківська обл.) }\end{array}$ & $450-500$ & G.pn.V \\
\hline
\end{tabular}

Кількісне дослідження сумарного вмісту флавоноїдів проводили спектрофотометричним методом. Відомо, що флавоноїди володіють значною інтенсивністю поглинання в УФ-ділянці спектру з наявністю певних максимумів поглинання при 320-380 нм (смуга I) та при 240-270 нм (смуга II) [1]. В основі визначення флавоноїдів лежить реакція комплексоутворення з $\mathrm{AlCl}_{3}$, у результаті якої відбувається сильний батохромний зсув смуги I. Це дозволяє виключити вплив інших БАР фенольної групи. Відсутність у розчині порівняння реактиву забезпечує виключення впливу забарвлених супутніх речовин досліджуваних екстрактів у ділянці максимального поглинання комплексу $\mathrm{AlCl}_{3}$ з сумою флавоноїдів [12]. При кількісному аналізі флавоноїдів спетрофотометричним методом в якості стандарту використовували рутин.

Досліджені корені та пагони дикорослих рослин, а також калюси тирличів повітряно висушували за кімнатної температури до постійної маси. Точну наважку (1 г) подрібненої сухої сировини екстрагували $70 \%$ етиловим спиртом протягом 30 хв у колбі зі зворотним 40 ISSN 2078-2357. Наук. зап. Терноп. нац. пед. ун-ту. Сер. Біол., 2020, № 3-4 (80) 
холодильником на киплячій водяній бані. Після охолодження колбу знову зважували і за необхідності додавали $70 \%$ спирт до початкової маси. Одержаний розчин фільтрували. 1 мл фільтрату вміщували в мірну колбу ємністю 25 мл, додавали 5 мл $2 \%$ розчину $\mathrm{AlCl}_{3}$ у $95 \%$ етанолі, об'єм розчину доводили $95 \%$ етанолом до мітки. Через 30 хв вимірювали оптичну густину отриманого розчину на спектрофотометрі СФ-46 (410 нм).

Розчином порівняння був розчин суміші 1 мл екстракту та 0,1 мл концентрованої оцтової кислоти, доведений 95 \% етанолом до мітки у мірній колбі ємністю 25 мл. Паралельно в тих же умовах вимірювали оптичну густину розчину, що вміщує 1 мл $0,005 \%$ розчину стандартного зразка рутину, який готували аналогічно досліджуваному розчину.

Вміст суми флавоноїдів (X, \%) у перерахунку на рутин і абсолютно суху сировину розраховували за формулою:

$$
\mathrm{X}=\frac{D_{1} \cdot m_{0} \cdot 25 \cdot 50 \cdot 100}{D_{0} \cdot m_{1} \cdot 25 \cdot 50 \cdot(100-w)}=\frac{D_{1} \cdot m_{0} \cdot 100}{D_{0} \cdot m_{1} \cdot(100-w)},
$$

де $\boldsymbol{D}_{\boldsymbol{l}}$ - оптична густина досліджуваного розчину; $\boldsymbol{D}_{0}$ - оптична густина розчину стандартного зразка рутину; $\boldsymbol{m}_{\boldsymbol{l}}$ - маса сировини, г; $\boldsymbol{m}_{\boldsymbol{0}}$ - маса рутину, г; $\boldsymbol{w}$ - втрата маси сировини при висушуванні.

Сумарний вміст ксантонів визначали за допомогою модифікованого нами хроматоспектрофотометричного методу $[2,9,10]$. Повітряно-суху сировину (корені та пагони дикорослих рослин тирличів, їхні калюси) гідролізували у суміші ацетону і води 1:1 (суміш А), що містила $5 \% \mathrm{HCl}$, на водяній бані протягом 1 години. На пластинку із целюлозою наносили три смуги досліджуваного екстракту та одну - розчину стандартного зразка мангіферину. Ще одну смугу залишали для приготування контрольного розчину. Після хроматографування у насиченій $15 \%$-ним розчином оцтової кислоти камері пластинку аналізували в УФ-світлі (360 нм). Відмічені на рівні плями стандартного зразка мангіферину зони, що містять ксантони, та рівну за площею ділянку целюлози на чистій смузі пластинки десорбували у суміші А. Оптичну густину профільтрованих розчинів визначали спектрофотометрично при 369 нм на фоні контрольного розчину.

Сумарний вміст ксантонів у досліджених зразках ( $X$, \% від маси абсолютно-сухої сировини) у перерахунку на мангіферин-стандарт вираховували за формулою:

$$
X=\frac{P_{1} \times V_{3} \times V_{4} \times D_{2} \times 100 \times 100}{V_{1} \times D_{1} \times P \times V_{2} \times(100-a)},
$$

де $\boldsymbol{V}_{\boldsymbol{I}}$ - об'єм розчину мангіферину-стандарту, мл; $\boldsymbol{V}_{\boldsymbol{2}}$ - об'єм екстракту, нанесеного на хроматограму, мл; $\boldsymbol{V}_{3}$ - об' єм розчину мангіферину-стандарту, нанесеного на хроматограму, мл; $\boldsymbol{V}_{\boldsymbol{4}}$ - об'єм екстракту, мл; $\boldsymbol{D}_{\boldsymbol{I}}$ - оптична густина розчину мангіферину-стандарту; $\boldsymbol{D}_{2}$ - оптична густина досліджуваного розчину; $\boldsymbol{P}$ - наважка сировини, г; $\boldsymbol{P}_{\boldsymbol{I}}$ - наважка мангіферинустандарту, г; $\boldsymbol{a}$ - втрата в масі при висушуванні сировини, \% від маси повітряно-сухої сировини.

Визначення сумарного вмісту флавоноїдів і ксантонів проводили у 3-5 повторностях у кожному варіанті досліду.

Дослідження вмісту БАР у культурах на поролонових підкладках проводили в кінці експерименту на 210-ту добу [13]. Для порівняння оцінювали вміст БАР у калюсах тирличів на агаризованих субстратах також у кінці експерименту.

Результати дослідження опрацьовували статистично [6].

\section{Результати досліджень та їх обговорення}

У результаті проведених досліджень встановлено, що вміст флавоноїдів і ксантонів у калюсній тканині кореневого походження G. punctata (брескульська популяція), яку вирощували у рідких середовищах на поролонових підкладках, в 1,16 та в 2,3 раза відповідно перевищував такі показники у калюсі на агаризованому субстраті (табл. 2, рис. 1). 
Вміст флавоноїдів і ксантонів у дикорослих рослинах видів роду Gentiana L.

\begin{tabular}{|c|c|c|c|c|}
\hline \multirow{2}{*}{ Зразки } & \multicolumn{2}{|c|}{ Вміст флавоноїдів у сухій масі, \% } & \multicolumn{2}{c|}{ Вміст флавоноїдів у сухій масі, \% } \\
\cline { 2 - 5 } & Пагони & Корені & Пагони & Корені \\
\hline G.1.Tr & $4,42 \pm 0,32$ & $0,46 \pm 0,02$ & $1,99 \pm 0,12$ & $0,43 \pm 0,02$ \\
\hline G.1.R & $9,76 \pm 0,69$ & $0,48 \pm 0,03$ & $3,92 \pm 0,21$ & $0,55 \pm 0,04$ \\
\hline G.p.Br & $9,06 \pm 0,63$ & $0,34 \pm 0,03$ & $3,42 \pm 0,23$ & $3,29 \pm 0,28$ \\
\hline G.ac.T & $5,33 \pm 0,39$ & $1,23 \pm 0,10$ & $2,11 \pm 0,11$ & $0,74 \pm 0,04$ \\
\hline G.asc.P & $2,95 \pm 0,21$ & $0,35 \pm 0,03$ & $0,42 \pm 0,03$ & $0,08 \pm 0,005$ \\
\hline G.pn.V & $1,14 \pm 0,09$ & не визначали & $0,10 \pm 0,006$ & не визначали \\
\hline G.cr.Kr & $2,54 \pm 0,23$ & $0,19 \pm 0,02$ & $0,40 \pm 0,03$ & $0,06 \pm 0,003$ \\
\hline G.cr.Med & $2,22 \pm 0,20$ & $0,14 \pm 0,01$ & $0,24 \pm 0,02$ & $0,05 \pm 0,005$ \\
\hline
\end{tabular}

Примітка. Розшифрування умовних позначень зразків див. у табл. 1.

Кількість флавоноїдів у калюсах G.p.Br, які вирощували як у рідкому живильному середовищі на поролонових підкладках, так і на агаризованому субстраті, була нижчою, ніж у пагонах дикорослих рослин (у 21,3 та 24,7 раза відповідно), однак дещо перевищувала (у випадку культури на поролоновому субстраті - у 1,3 раза) або ж була практично такою ж (у випадку культури на агаризованому субстраті), як в коренях інтактних рослин (рис. 1, табл. 2). Сумарний вміст ксантонів у калюсних тканинах, які вирощували як на агаризованому субстраті, так і в рідкому середовищі, був нижчим порівняно з таким і в пагонах (у 6,6 раза та 2,9 раза відповідно), і в коренях інтактних рослин (у 6,4 раза та 2,8 раза відповідно) (рис.1, табл. 2).

У калюсі кореневого походження G. asclepiadea (пожижевська популяція), що вирощувався на поролонових субстратах у рідкому живильному середовищі, вміст флавоноїдів у 1,6 раза перевищував аналогічний показник у калюсі з агаризованого середовища, тоді як кількість ксантонів у культурах з обох субстратів була практично однаковою (табл. 2, рис. 2).

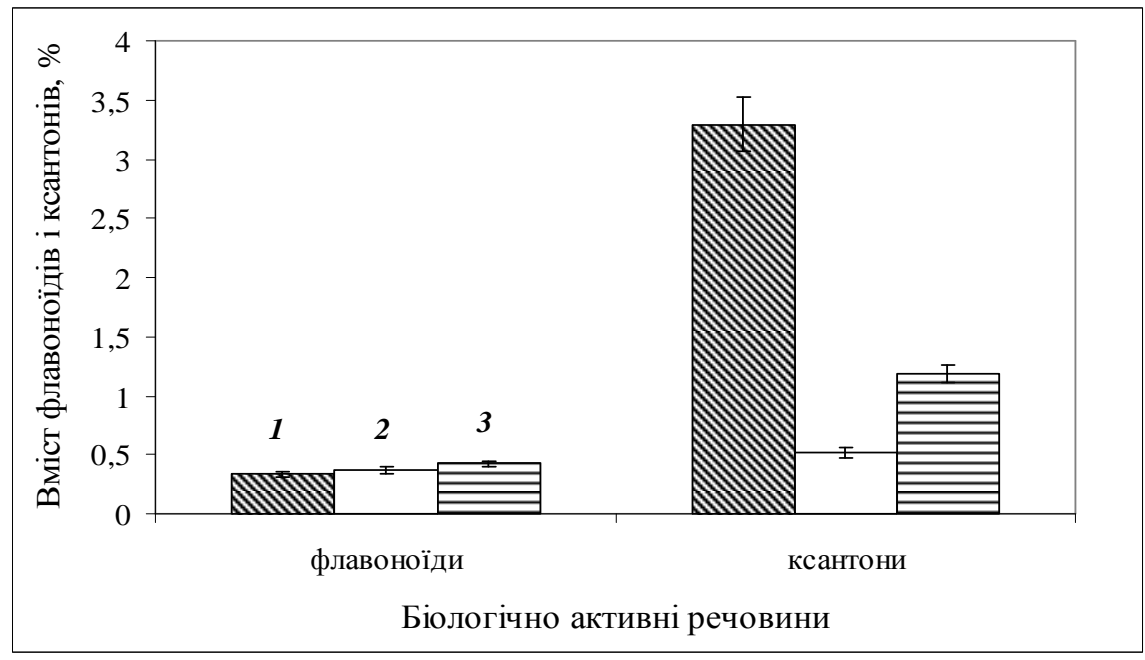

Рис. 1. Вміст флавоноїдів і ксантонів у зразках G. punctata (брескульська популяція): 1 - корені інтактних рослин; 2 - калюс на агаризованому субстраті; 3 калюс на поролонових підкладках 
Вміст флавоноїдів у калюсах G.asc.P, які вирощували як у рідкому живильному середовищі на поролонових підкладках, так і на агаризованому субстраті, був нижчим, ніж у пагонах (у 5 та 7,7 раза відповідно), однак дещо перевищував (у випадку культури на поролонових субстратах в 1,7 раза) або ж був практично таким же (у випадку культури на агаризованому субстраті), як в коренях дикорослих рослин. Сумарний вміст ксантонів у калюсних тканинах, які вирощували як на агаризованому субстраті, так і на поролонових підкладках, перевищував такий у коренях (у 5,8 раза та 6 разів відповідно) і несуттєво перевищував - у пагонах інтактних рослин (рис. 2, табл. 2).

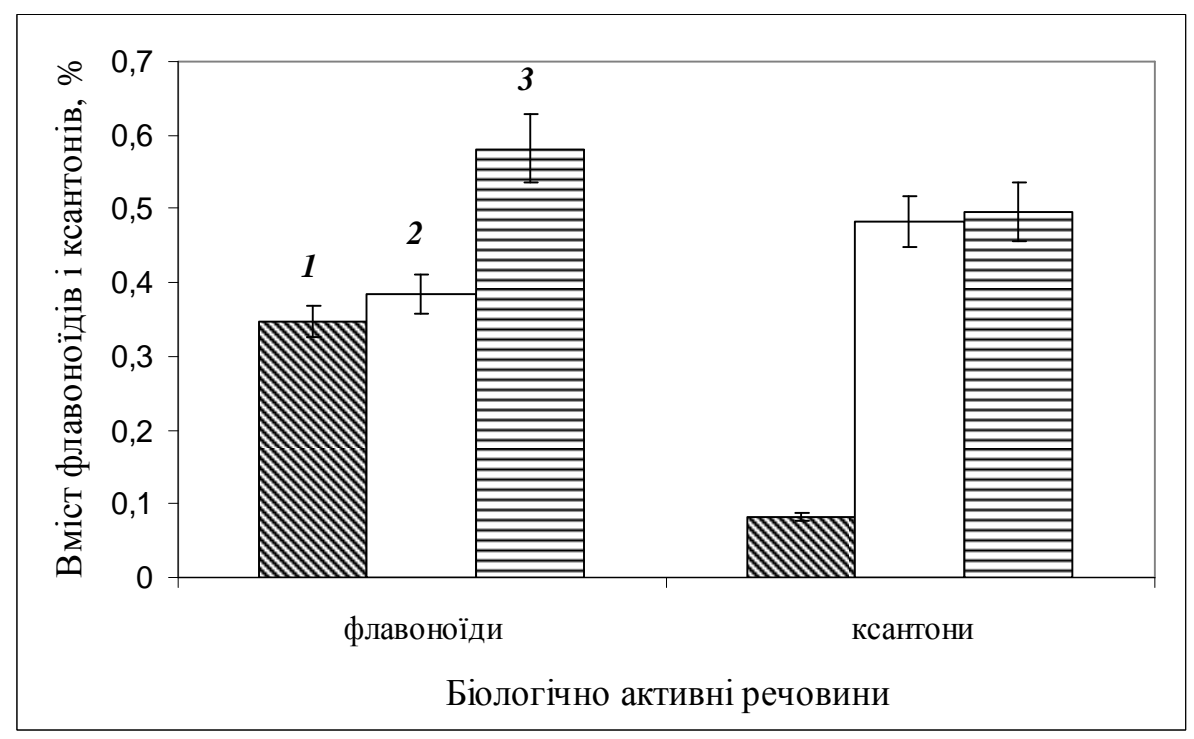

Рис. 2. Вміст флавоноїдів і ксантонів у зразках G. asclepiadea (пожижевська популяція): 1 - корені інтактних рослин; 2 - калюс на агаризованому субстраті; 3 калюс на поролонових підкладках

Вміст флавоноїдів і ксантонів у калюсних тканинах кореневого походження G. cruciata (медоборська популяція), які культивували у рідких середовищах на поролонових підкладках, був у 1,3 та 1,4 раза нижчим порівняно 3 культурами на агаризованому середовищі (табл. 2 , рис. $3 A$ ). Кількість флавоноїдів і ксантонів у калюсах G.cr.Med, які вирощували як на агаризованому субстраті, так і у рідкому живильному середовищі на поролонових підкладках, була нижчою, ніж у пагонах (флавоноїдів - у 4,6 та 5,9 раза відповідно, ксантонів - у 1,8 та 2,5 раза відповідно), однак перевищувала таку в коренях інтактних рослин (флавоноїдів - у 3,4 та 2,6 раза відповідно, ксантонів - у 2,9 та 2 рази відповідно) (табл. 2, рис. $3 A$ ).

При дослідженні калюсних тканин кореневого походження G. cruciata 3 іншої популяції (с. Креничі) встановлено, що вміст флавоноїдів і ксантонів у культурах з рідкого живильного середовища 3 поролоновими підкладками у 1,5 рази перевищує такі показники для культур 3 агаризованого середовища (табл. 2, рис. 3Б). Кількість флавоноїдів і ксантонів у калюсах G.cr.Kr, які вирощували як на агаризованому субстраті, так і у рідкому живильному середовищі на поролонових підкладках, була нижчою, ніж у пагонах (флавоноїдів - у 24,7 та 16,2 раза відповідно, ксантонів - у 13,8 та 9,4 раза відповідно) та коренях інтактних рослин (флавоноїдів - у 1,8 та 1,2 раза відповідно, ксантонів - у 2,3 та 1,6 раза відповідно) (табл. 2, рис. 3 Б)

У результаті проведених досліджень нами встановлено, що вміст флавоноїдів у калюсних тканинах кореневого походження G. lutea (трояська популяція), які вирощували на агаризованому субстраті, у 1,4 раза перевищував такий порівняно 3 культурою 3 рідкого живильного середовища, тоді як кількість ксантонів у калюсах 3 обох субстратів була практично однаковою (табл. 2, рис. $4 A$ ). 
Сумарний вміст БАР у калюсах G.l.Tr, які вирощували як у рідкому живильному середовищі на поролонових підкладках, так і на агаризованому субстраті, був нижчим, ніж у пагонах інтактних рослин (флавоноїдів - у 9,2 та 6,5 раза відповідно, ксантонів - у 1,7 та 1,6 раза відповідно).

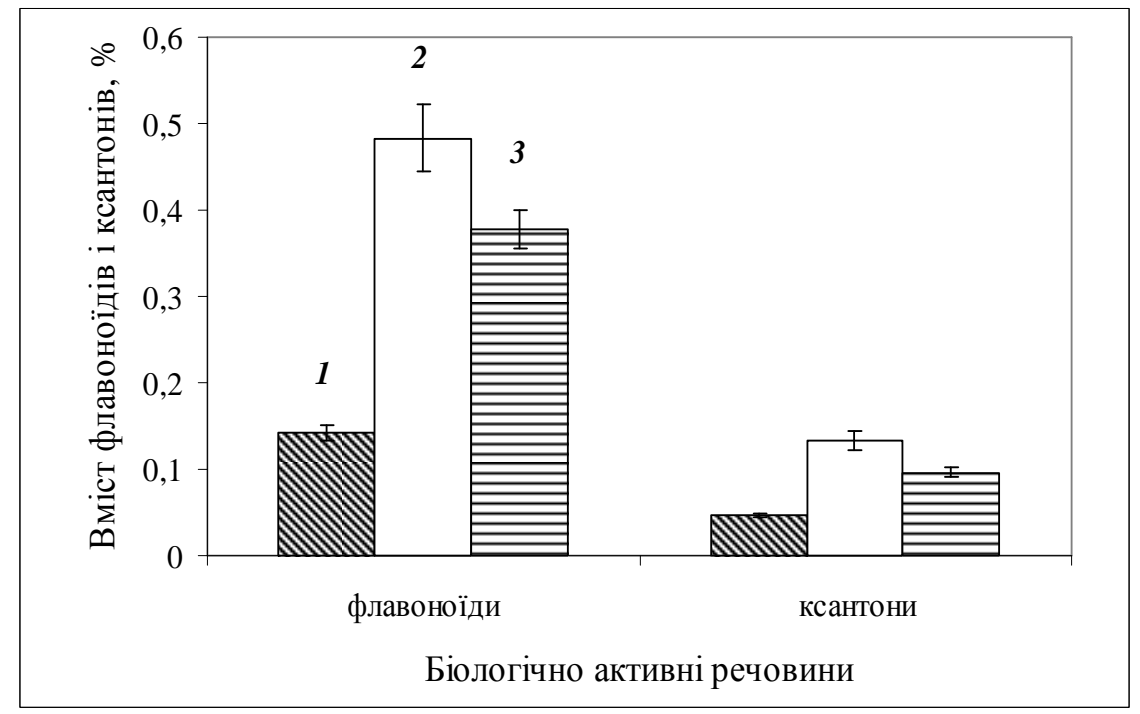

$A$

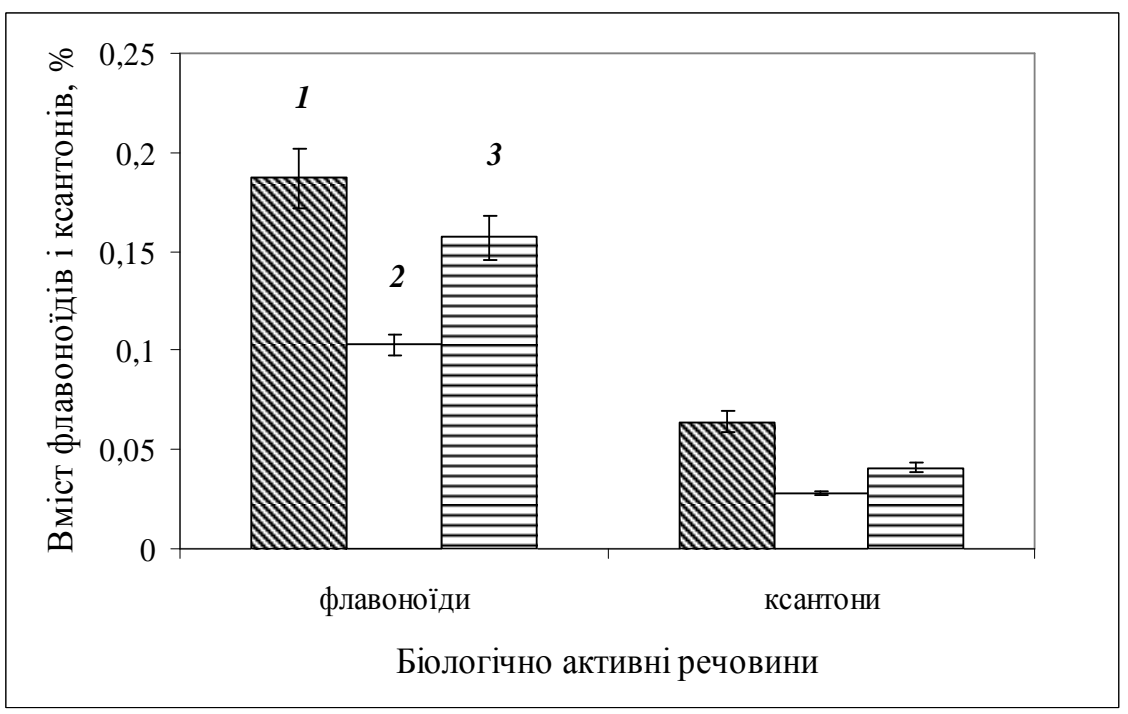

Б

Рис. 3. Вміст флавоноїдів і ксантонів у зразках G. cruciata з медоборської $(A)$ та креничської (Б) популяцій: 1 - корені інтактних рослин; 2 - калюс на агаризованому субстраті; 3 - калюс на поролонових підкладках

Кількість флавоноїдів у калюсній культурі G.l.Tr, яку вирощували у рідкому живильному середовищі на поролонових підкладках, була майже такою ж, як в коренях інтактних рослин, тоді як вміст цих вторинних метаболітів у культурі з агаризованого субстрату був в 1,5 рази вищим, ніж у коренях. Сумарний вміст ксантонів в обох культурах був у 2,6-2,8 раза вищим, ніж у коренях рослин (табл. 2 , рис. $4 A$ ).

При дослідженні калюсних тканин кореневого походження G. lutea (рогнєська популяція), встановлено, що вміст флавоноїдів і ксантонів у культурі, яку вирощували у рідкому на поролонових підкладках живильному середовищі, перевищував у 1,2 раза такі показники у культурі з агаризованого середовища (табл. 2, рис. 4Б). Кількість досліджених 44 ISSN 2078-2357. Наук. зап. Терноп. нац. пед. ун-ту. Сер. Біол., 2020, № 3-4 (80) 
вторинних метаболітів у калюсах G.1.R, які вирощували як у рідкому, так і на агаризованому живильних середовищах, була нижчою, ніж у пагонах інтактних рослин (флавоноїдів - 18,7 та 23 рази відповідно, ксантонів - у 4,6 та 5,3 раза відповідно).

Суттєвих відмінностей вмісту флавоноїдів в калюсних культурах та в коренях інтактних рослин нами не виявлено. Кількість ксантонів у калюсах з обох субстратів була у 1,3-1,5 раза більшою, ніж у коренях рослин (табл. 2 , рис. $4 Б$ ).

Вміст флавоноїдів і ксантонів у калюсних тканинах кореневого походження G. acaulis (туркульська популяція), які вирощували на агаризованому середовищі був практично таким же, як у калюсах, які культивували у рідких середовищах на поролонових підкладках (табл. 2, рис. 5).

Кількість флавоноїдів і ксантонів у культурах G.ac.T, які вирощували як на агаризованому субстраті, так і у рідкому живильному середовищі на поролонових підкладках, була нижчою, ніж у пагонах (флавоноїдів - у 3,8, ксантонів - в 1,8 та 2 рази відповідно), однак, перевищувала (у випадку ксантонів - в 1,6 та 1,4 раза відповідно), або несуттєво відрізнялася (у випадку флавоноїдів) від такої в коренях інтактних рослин (табл. 2, рис. 5).

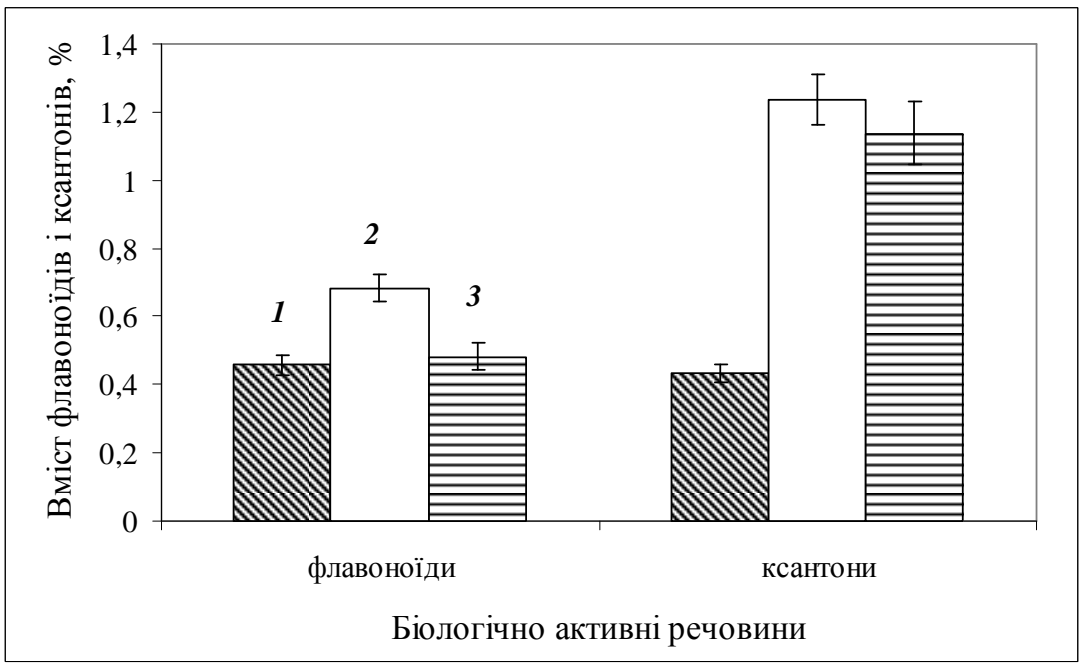

$A$

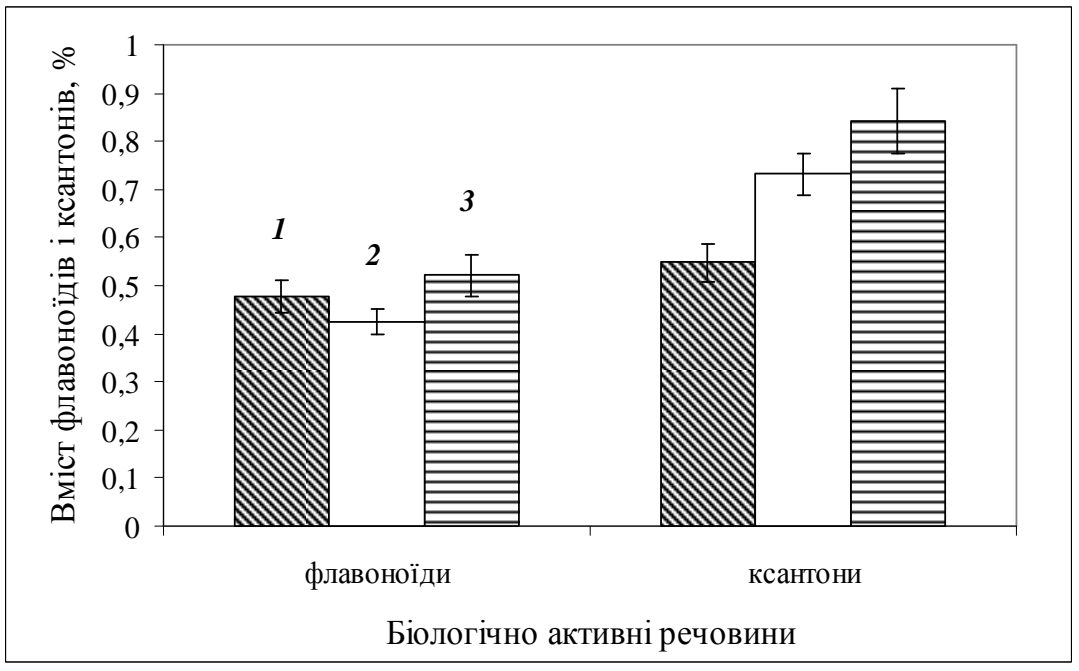

Б

Рис. 4. Вміст флавоноїдів і ксантонів у зразках G. lutea 3 трояської $(A)$ та рогнєської (Б) популяцій: 1 - корені інтактних рослин; 2 - калюс на агаризованому субстраті; 3 - калюс на поролонових підкладках

ISSN 2078-2357. Наук. зап. Терноп. нац. пед. ун-ту. Сер. Біол., 2020, № 3-4 (80) 


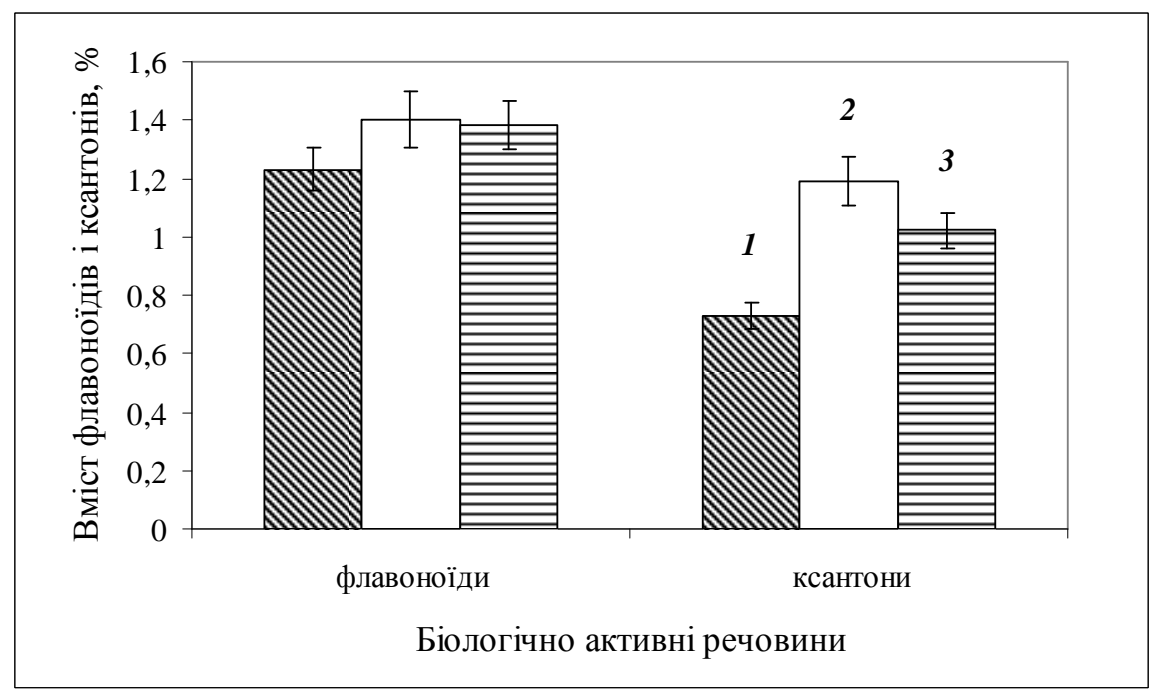

Рис. 5. Вміст флавоноїдів і ксантонів у зразках G. acaulis (туркульська популяція): 1 - корені інтактних рослин; 2 - калюс на агаризованому субстраті; 3 - калюс на поролонових підкладках

У калюсній культурі G.pn.V, яку вирощували на агаризованому і рідкому на поролонових підкладках живильних середовищах, флавоноїдів і ксантонів нами не виявлено.

Раніше нами встановлено, що адаптація культури тканин тирличів до росту у рідкому живильному середовищі на поролонових підкладках залежала від виду та генотипу вихідного експланта. Найбільший стимулюючий ефект вирощування у рідкому живильному середовищі на поролонових підкладках виявлено для калюсів G. punctata (брескульська популяція), G. asclepiadea (пожижевська популяція) - 170,1 \% та 151,7 \% відповідно [4, 13]. Для більшості калюсних культур тирличів: G. punctata (брескульська популяція), G. asclepiadea (пожижевська популяція), G. cruciata (креничська популяція), G. lutea (рогнєська популяція), вирощування у рідкому живильному середовищі на поролонових підкладках дозволяє підвищити як приріст біомаси калюсу (в 1,3-1,7 раза), так і вміст у ньому флавоноїдів (в 1,2-1,6 раза) і ксантонів (в 1,2-2,3 раза) порівняно 3 тими ж культурами на агаризованих середовищах. Для калюсів G. cruciata (медоборська популяція) та G. lutea (трояська популяція) на рідких з поролоновими підкладками середовищах як індекс росту за сирою масою, так і вміст вторинних метаболітів, нижчі порівняно з культурами з агаризованого середовища. Ріст калюсу G. acaulis (туркульська популяція) на середовищі з поролоновими підкладками відбувається інтенсивніше, ніж на агаризованому $[4,7]$, однак вміст БАР при цьому дещо зменшується

\section{Висновки}

Проведені дослідження показали здатність калюсів тирличів, які вирощували у рідких живильних середовищах на поролонових субстратах, до синтезу флавоноїдів і ксантонів. Вміст флавоноїдів і ксантонів у культурі тканин, які вирощували у рідких живильних середовищах, перевищував (G. punctata, брескульська популяція, G. asclepiadea, пожижевська популяція, G. cruciata, креничська популяція та G. lutea, рогнєська популяція), був близьким (G. acaulis, туркульська популяція) або нижчим (G. cruciata, медоборська популяція, G. lutea, трояська популяція) порівняно 3 такими показниками у відповідних калюсах на агаризованих субстратах. У калюсі G. pneumonanthe (вигодська популяція) при культивуванні як на агаризованому середовищі, так і у рідкому на поролонових підкладках середовищі, флавоноїдів і ксантонів не виявлено.

Вміст флавоноїдів і ксантонів у більшості калюсних культур, які вирощували як на агаризованому, так і на поролоновому субстратах, був більшим або близьким до такого в коренях дикорослих рослин, але нижчим порівняно з їхніми пагонами. 
Отже, розроблений нами спосіб культивування калюсних тканин тирличів у рідких живильних середовищах на поролонових підкладках дозволяє зменшити економічні затрати, замінивши агар на поролонові підкладки, а також збільшити як приріст біомаси більшості культур, так і вміст у них флавоноїдів і ксантонів.

1. Беликов В. В., Шрайбер М. С. Методы анализа флавоноидных соединений. Фармащия. 1970. № 1. C. 66-71.

2. Государственная фармакопея СССР. ХІ изд. Вып. 2: Общие методы анализа. Лекарственное растительное сырье. Москва : Медицина, 1990. С. 312-314.

3. Грицик А. Р., Бензель Л. В, Цвеюк Н. П. Використання рослин видів роду Тирлич (Gentiana L.) в медицині. Фармаи. журн. 2003. № 2. С. 91-97.

4. Дробик Н. М. Фізіолого-біохімічні та генетичні основи біотехнології видів роду Gentiana L.: дис. ... доктора біологічних наук: 03.00.20 / Інститут молекулярної біології та генетики НАН України. Київ, 2009. $346 \mathrm{c}$.

5. Кунах В. А. Біотехнологія лікарських рослин. Генетичні та фізіолого-біохімічні основи. Київ : Логос, $2005.730 \mathrm{c}$.

6. Лакин Г. Ф. Биометрия: Учебное пособие для биологических специальностей вузов. Москва : Высш. школа, 1980. 293 с.

7. Леськова О. М, Страшнюк Н. М., Загричук Г. Я., Мельник В. М. Біологічно активні речовини видів роду Gentiana L. 2. Вміст ксантонів у рослинах Українських Карпат. Фітотерапія. Часопис. 2006. №3. C. 53-55.

8. Лікарські рослини: енциклопедичний довідник / А. П. Лебеда та ін.; відп. ред. А. М. Гродзінський. К. : В-во «Українська Радянська Енциклопедія» ім. М. П. Бажана, Український виробничокомерційний центр «Олімп», 1992. С. 430-432.

9. Лубсандоржиева П. Б., Николаева Г. Г., Глызин В. И. и др. Содержание мангиферина у видов сем. Gentianaceae. Pacmum. pecypcb. 1986. Т. 21, вып. 2. С. 233-236.

10. Николаева Г. Г. Фитохимическое исследование растений семейства горечавковых флоры Сибири: дис. ... доктора фармацевт. наук: 15.00.02. Москва, 2000. С. 34-50.

11. Растительные ресурсы СССР: Цветковые растения, их химический состав, использование; Семейства Caprifoliaceae - Plantaginaceae. Л. : Наука, 1990. 328 с.

12. Селиванчикова И. Б., Лякина М. Н., Костенникова 3. П. Количественное определение флавоноидов в гомеопатических настойках туи методом спектрофотометриии. Фармащия. 2001. № 6. С. 14-16.

13. Спосіб вирощування калюсної тканини тирличу крапчастого (Gentiana punctata L.): пат. 23470 Україна: МПК(2006) С12N, 5/04 А01Н 4/00. № u 200700178; заявл. 09.01.2007; опубл. 25.05.2007, Бюл. № 7.

14. Страшнюк Н. М., Леськова О. М, Загричук Г. Я., Мельник В. М., Кунах В. А. Біологічно активні речовини видів роду Gentiana L. 1. Біосинтез та фізіологічна дія. Фітотерапія. Часопис. 2006. № 1. C. $31-41$.

15. Червона книга України. Рослинний світ / За ред. Я. П. Дідуха. К. : Глобалконсалтинг, 2009. 900 с.

16. Drobyk N. M., Mel'nyk V. M., Twardovska M. O., Konvalyuk I. I., Kunakh V. A. Tissue and Organ Cultures of Gentians as Potential Sources of Xanthones and Flavonoids. In: The Gentianaceae. Vol. 2. Biotechnology and Applications. / Ed. by. Rybczyński J. J., Davey M. R., Mikula A. Heidelberg, New York, Dordrecht, London: Springer, 2015. P. 307-317.

17. Yang J. L., Liu L. L., Shi Y. P. Phytochemicals and biological activities of Gentiana species. Nat. Prod. Commun. 2010. Vol. 5, 4. P. 649-664. https://doi.org/10.1177/1934578X1000500432

\section{References}

1. Belikov V. V., Shrayber M. S. Metody analiza flavonoidnykh soedineniy. Farmatsiia. 1970. No1. S. 66-71. [in Russian]

2. Gosudarstvennaia farmakopeia SSSR. XI izd. Vyp. 2: Obshchie metody analiza. Lekarstvennoe rastitel'noe syr'e. Moskva : Meditsina, 1990. S. 312-314. [in Russian]

3. Hrytsyk A. R., Benzel' L. V, Tsveiuk N. P. Vykorystannia roslyn vydiv rodu Tyrlych (Gentiana L.) v medytsyni. Farmats. zhurn. 2003. No2. S. 91-97. [in Ukrainian]

4. Drobyk N. M. Fizioloho-biokhimichni ta henetychni osnovy biotekhnolohii vydiv rodu Gentiana L.: dys.... doktora biolohichnykh nauk: 03.00.20 / Instytut molekuliarnoi biolohii ta henetyky NAN Ukrainy. Kyiv, 2009. 346 s. [in Ukrainian] 
5. Kunakh V. A. Biotekhnolohiia likars'kykh roslyn. Henetychni ta fizioloho-biokhimichni osnovy. Kyiv: Lohos, 2005. 730 s. [in Ukrainian]

6. Lakin G. F. Biometriia: Uchebnoe posobie dlia biologicheskikh spetsial'nostey vuzov. Moskva: Vyssh. shkola, 1980. 293 s. [in Russian]

7. Les'kova O. M, Strashniuk N. M., Zahrychuk H. Ya., Mel'nyk V. M. Biolohichno aktyvni rechovyny vydiv rodu Gentiana L. 2. Vmist ksantoniv u roslynakh Ukrains'kykh Karpat. Fitoterapiia. Chasopys. 2006. No3. C. 53-55. [in Ukrainian]

8. Likars'ki roslyny: entsyklopedychnyy dovidnyk / A. P. Lebeda ta in.; vidp. red. A. M. Hrodzins'kyy. K. : Vvo «Ukrains'ka Radians'ka Entsyklopediia» im. M. P. Bazhana, Ukrains'kyy vyrobnycho-komertsiynyy tsentr «Olimp», 1992. S. 430-432. [in Ukrainian]

9. Lubsandorzhieva P. B., Nikolaeva G. G., Glyzin V. I. i dr. Soderzhanie mangiferina u vidov sem. Gentianaceae. Rastit. resursy. 1986. T. 21, vyp. 2. S. 233-236. [in Russian]

10. Nikolaeva G. G. Fitokhimicheskoe issledovanie rasteniy semeystva gorechavkovykh flory Sibiri: dis. ... doktora farmatsevt. nauk: 15.00.02. Moskva, 2000. S. 34-50. [in Russian]

11. Rastitel'nye resursy SSSR: Tsvetkovye rasteniia, ikh khimicheskiy sostav, ispol'zovanie; Semeystva Caprifoliaceae - Plantaginaceae. L. : Nauka, 1990. 328 s. [in Russian]

12. Selivanchikova I. B., Liakina M. N., Kostennikova Z. P. Kolichestvennoe opredelenie flavonoidov v gomeopaticheskikh nastoykakh tui metodom spektrofotometriii. Farmatsiia. 2001. No6. S. 14-16. [in Russian]

13. Cposib vyroshchuvannia kaliusnoi tkanyny tyrlychu krapchastoho (Gentiana punctata L.): pat. 23470 Ukraina: MPK(2006) S12N, 5/04 A01H 4/00. No u 200700178; zaiavl. 09.01.2007; opubl. 25.05.2007, Biul. No7. [in Ukrainian]

14. Strashniuk N. M., Les'kova O. M, Zahrychuk H. Ya., Mel'nyk V. M., Kunakh V. A. Biolohichno aktyvni rechovyny vydiv rodu Gentiana L. 1. Biosyntez ta fiziolohichna diia. Fitoterapiia. Chasopys. 2006. No1. C. 31-4. [in Ukrainian]

15. Chervona knyha Ukrainy. Roslynnyy svit / Za red. Ya. P. Didukha. K. : Hlobalkonsaltynh, 2009. 900 s. [in Ukrainian]

16. Drobyk N. M., Mel'nyk V. M., Twardovska M. O., Konvalyuk I. I., Kunakh V. A. Tissue and Organ Cultures of Gentians as Potential Sources of Xanthones and Flavonoids. In: The Gentianaceae. Vol. 2. Biotechnology and Applications. / Ed. by. Rybczyński J. J., Davey M. R., Mikula A. Heidelberg, New York, Dordrecht, London: Springer, 2015. P. 307-317.

17. Yang J. L., Liu L. L., Shi Y. P. Phytochemicals and biological activities of Gentiana species. Nat. Prod. Commun. 2010. Vol. 5, 4. P. 649-664. https://doi.org/10.1177/1934578X1000500432

\author{
${ }^{l}$ L. R. Hrytsak ${ }^{2}$ V.M. Mel'nyk, ${ }^{1}$ M. Z. Prokopyak, ${ }^{l}$ O. Yu. Mayorova, ${ }^{l}$ Kh. M. Kolisnyk, ${ }^{1}$ N. M. Drobyk \\ ${ }^{1}$ Volodymyr Hnatiuk Ternopil National Pedagogical University, Ukraine \\ ${ }^{2}$ Institute of Molecular Biology and Genetics, NAS of Ukraine
}

\title{
THE CONTENT OF FLAVONOIDS AND XANTHONES IN CALLUS CULTURES OF GENTIANA L. PLANT SPECIES GROWN IN LIQUID MEDIUM ON FOAM SUBSTRATES
}

The content of flavonoids and xanthones in callus cultures derived from the roots of plants of six species of Gentiana L. genus was studied during the cultivation of these cultures in liquid growth media on foam substrates. The research findings indicate that for most callus cultures, which were grown on both agar and foam substrates, the content of biologically active substances (BAS) was higher or close to that in the roots of wild plants, but lower compared to their shoots.

The content of flavonoids and xanthones in tissue cultures grown in liquid nutrient media exceeded (G. punctata, Mt. Breskul, G. asclepiadea, Mt. Pozhyzhevska, G. cruciata, Krenychi village and $G$. lutea, Mt. valley Rohnechska), was close ( $G$ acaulis, Mt. Turkul) or lower (G. cruciata, «Medobory» Nature Reserve, G. lutea, Mt. Troyaska) compared to those in the corresponding calluses on agar substrates. In the callus of G. pneumonanthe (Vyhoda village) during cultivation on agar medium and in liquid medium on foam substrates, flavonoids and xanthones were not detected.

For most callus cultures of gentians: G. punctata (Mt. Breskul), G. asclepiadea (Mt. Pozhyzhevska), G. cruciata (Krenychi village), G. lutea (Mt. valley Rohnechska), cultivation in a liquid growth medium on foam substrates can increase the growth of callus biomass (1.3-1.7 times) and the content of flavonoids (1.2-1.6 times) and xanthones (1.2-2.3 times) in comparison with the same cultures on agar media. For the callus of G. cruciata («Medobory» Nature Reserve) and G. lutea 
(population of Mt. Troyaska) on liquid media with foam substrates, both the growth index by fresh weight and the content of secondary metabolites are lower compared to cultures from agar medium. The growth of callus G. acaulis (Mt. Turkul) on the nutrient medium with foam substrates is more intense than on agar, but with lowered BAS.

Thus, the developed method of cultivating callus tissues of gentians in liquid nutrient media on foam substrates can reduce costs by replacing agar with foam substrates, as well as increase both the yield of biomass of most callus cultures and their ability to synthesize and accumulate flavonoids and xanthones.

Key words: Gentiana L. species, in vitro cultures, foam substrates, flavonoids, xanthones.

Надійшла 18.11.2020. 